\title{
The Brandt Report: Survival of a Programme?
}

\section{Reginald Herbold Green}

What limits our response to this challenge ...? the non-existence of a clear and generalised awareness of the realities and dangers and the absence of political will to face up to them and take corrective action.

Brandt Report (pp 267-8)

It is probably an accurate observation that in conditions of uncertainty there is a preference to do nothing. By default. if for no other reason, it seems probable ... the Brandt Report will enter the history books as just another well-intentioned Report that in practical terms led to nothing. Graham Bird ${ }^{1}$

The purpose of the Brandt Report is to convey a message ... it does so effectively and with conviction. The intentions . . are admirable . . But the message as a whole is not credible, because the conception of the world on which it rests is false.

\section{P. D. Henderson ${ }^{2}$}

There are several mutual economic interests, (but) these are not sufficiently compelling to .. make Western governments, including Britain's, give NorthSouth relations a higher priority than they do. Two major elements are. however, missing from the economic argument. One is some awareness of the political as well as economic importance of having an international order or 'nules of the game'... Second there are moral as well as economic and political considerations ... If there is a case for the British Government to be more involved in alleviating their poverty it is in the first instance a moral one...

Vincent Cable ${ }^{3}$

This failure to understand the enormous economic potential of less wealthy developing countries both as markets and as suppliers is compounded by two further misconceptions. The first is to see existing international economic and financial arrangements as essentially healthy and adequate... The next misconception is to pin the blame for the world's economic malaise on OPEC... Edward Heath ${ }^{4}$

\section{Kicked into Obscurity?}

In the United Kingdom at least the question is no longer whether the Brandt Report's proposals constitute an adequate and appropriate programme for survival: it is whether they will survive as a serious focus for political debate and action. At the moment, Programme for Survival seems well on the way to joining its phenomenally ineffective and ill-timed predecessor Partners in Development (Pearson Report) in the obscurity of academic stacks and footnotes.

Why has this happened? On the face of it the Brandt Report had several marks in its favour. It was a unanimous report of a number of statesmen and thinkers from major First and Third World countries, which had both a clear message and a technically (and conceivably politically) practicable programme. That programme was a blend of radical reformist capitalism (on the production side) and quasi-egalitarian social democracy (on the distribution and regulation side) - a blend that, on the face of it, has potential appeal to both major British parties. Further, the Report uses a 'mutual interest' economic case for the rules of the game, and it argues for the reform of the international economic order to augment (not supplant) the moral case for the eradication of absolute poverty.

Further, the Brandt Report is the only systematic programme for global economic restructuring now on the political market with any real chance of acceptance. There is no serious conservative northern alternative. The radical southern alternatives may be coherent and intellectually plausible, but on the one hand they cannot be expected to be achieved without compromise and on the other they tend to assume that the Old International Economic Order works well for industrial economies, ignoring the fact that it has been overtaken by the New International Economic Disorder.

One drawback is clear. While Programme for Survival does see the economic order as in growing disorder, its authors did not in 1977-79 envisage the degree of crisis in northern economies which has characterised 198081 and made northern political leaders more inwardlooking. They are now even less willing to consider the Commissioner's claim that improvement in NorthSouth relations is part of the 'solution' and rigid resistance to restructuring itself part of the 'problem'. But that alone seems inadequate to explain the very limited practical response to Brandt even in the UK. Nor can one argue that the Brandt Report's failure lies in intellectual weakness per se. Programme for Survival is a contribution to policy debate, not an academic model, a sketch map for how to devise programmes, not a blueprint. Such documents rarely succeed or fail primarily on academic merit, and Brandt is by no means self evidently wrong, empirically or theoretically.

Bulletin. 1981. vol 12 no 2. Institute of Development Studies. Sussex 
Indeed, as a policy document and guide to action it rates rather well.

\section{Ideological Resistance}

Yet it is in a related area that we find the root of the hostility and inaction. It is ideological opposition that has constituted the most effective barrier to action even in the UK. (In the Third World and in socialist Europe the basis for ideological objection is more obvious. $)^{6}$

The support and opposition for the Brandt Report-or international structural change more generally-do not however fit the simple division between capital and labour (or business and unions). ${ }^{7}$ Some businesses see profit in more trade and more aid. Those oriented to Third World markets and those dealing in Third World imports are examples. Inversely, firms affected by imports favour trade restrictions and put the pressure on Third World sources in particular because they are seen as politically vulnerable (though calls for restrictions against socialist Europe, Japan and the USA are growing too). In addition, firms whose profits depend on specialist knowledge of uncertain markets and on frequent price changes-eg commodity merchants and brokers-have vested interests in opposing stabilisation, whatever merits it might have for producers and consumers or in reducing the macro economic costs associated with rapid price and balance of payments changes.

Unions tend to take the same stance as their employers on these issues since they affect firms, workers and communities alike. While the running on restrictionism is made by firms, unions are just as concerned about 'cheap imports'; and genuine general concern about solidarity or broad mutual interest is effective in particular union decisions only if job security is not threatened.

\section{The force of uncertainty}

By contrast, uncertainty is a potent and unambiguous force against implementing even the Brandt Report's initial programme. As Bird" makes clear, there are two elements to the matter the existence of an alternative explanation" of the present crisis which implies a different cure, and the fact that the effects of any major structural change are always uncertain and cannot be foretold before it is implemented.

In a slightly different way Henderson" raises a number of questions about Programme for Survival's implicit analysis, in particular whether demand stimulation is appropriate and whether the international context is the dominant cause of the Third World's economic problems." While no alternative model for NorthSouth relations emerges, the general effect, as intended, is to stress the uncertainty of the outcome of implementing Brandt, to cast doubt as to whether it would be a good thing.

When resources are limited and a series of crises confronts a Cabinet, a firm, a party or a union, there is a tendency to avoid taking major, resource-intensive decisions whose effects are perceived as uncertain. This inertia can be overcome-eg, the present UK Government's refinement and intensification of Chancellor Healey's main policies is extremely uncertain of outcome. This, however, requires both a belief that a change of course is essential and intense commitment to specific changes in the 'national' interest.

Few major politicians, businessmen or trade unionists see North-South relations (beyond OPEC) as crucial to overcoming Britain's economic crisis. ${ }^{12}$ (Mr Heath is an exception, as is Mrs Hart and perhaps Mr Steel; on occasion Lord Carrington and Sir Ian Gilmour have appeared partially convinced.) They view the present situation as marginally unsatisfactory and improvements as postponeable. Therefore, under conditions of uncertainty they are not prepared to devote substantial attention or resources to attempting major changes - a tendency heavily reinforced by the working patterns of both private and public sector bureaucracies which, pari passu. opt for the "tried and true', the relatively certain, the low risk rather than the innovative. ${ }^{13}$

\section{Alternative explanations of and remedies for the crisis}

If one accepts that too much money creation in relation to production is the main cause of current economic problems, and that the primary remedy is to squeeze monetary expansion, then demand reflation is a counterproductive prescription. Broadly speaking that is the dominant position within the present British Government, many middle class professionals and bureaucrats and fractions of the financial, commercial and industrial communities. ${ }^{14}$

A variant of this critique derives from the current IMF analysis ${ }^{15}$ which gives priority to the control of inflation, specifically to restoring the balance between supply and demand by cutting the latter (especially by reducing real wages), not raising the former. However, the IMF is concerned about the cost-push effects of undercapacity operation, and actually favours both recycling/ transfer of international liquidity and energy price/ production management approaches which are compatible with the Brandt proposals. Nevertheless, in its stress on money supply growth, demand pull and institutional structures (labour, business practices, state spending) as primary causes of inflation it does agree with the monetarists that renewed growth to bring 
output up (thus equalising demand) and reducing cost push inflation by spreading costs (higher productivity) are unattainable.

1945-70 was clearly a 'golden age' for industrial capitalist economies, and its restoration has immense crossclass domestic appeal. During this period, the Third World also had more rapid growth than before and on average more rapid percentage growth of output than industrial economies. ${ }^{16}$ On this interpretation the Old International Economic Order was broadly favourable to the south, and the wide divergence of growth rates relate largely to national action or inaction and to inherent resource inequalities quite beyond remedy by Brandt type proposals. In its purist-Kissinger in 1975-or revisionist-Richard Cooper in 1979-form this interpretation leads to a commitment to roll back the post-1974 (arguably post-1970) New International Economic Disorder by re-establishing the old order with minor adjustments, rather than adopt $A$ Programme for Survival s structural changes.

For governments like the British committed to reducing government intervention at home and for those who believe that reducing government market intervention/ management is the key to greater output and efficiency, ${ }^{17}$ extending the type of controls advocated in the Brandt Report is hardly an attractive proposition. The Brandt Report is frankly interventionist. While no advocate of physical allocation by directive, its philosophy is clearly one of managed markets with a substantial number of structural and discretionary controls. For example, it wishes to see business practices and anticartel frameworks of the type embodied in most capitalist industrial economies extended to cover international business relations, and believes indicative forward planning backed by finance can assure more stable (and larger) supplies of key commodities, alleviating both physical bottlenecks and the costs of rapid price swings. The alternative position is that existing national market management works badly enough to reduce actual production, raise costs and promote inflation, and that globalising it à la Brandt will have even greater costs. Business is rather more ambivalent about this-a general dislike for state intervention and management is usually combined with a number of more sharply focussed demands for particular intervention and management.

From the monetarist and anti-interventionist objections flows another. In its simple form, it runs that if too much money is the root of much evil, and too much government is the root of more, then rising public expenditure is the square root of all evil. In a more sophisticated form the argument starts from the facts that the UK is now a middle sized, middle income economy with declining relative-and, recently, absolute-economic capacity, which is undergoing a crisis. Therefore, it is necessary to sort out the domestic crisis before the UK can reasonably be expected to pay enhanced attention to Third World problems and, in any event, the UK's resources and role must increasingly be limited to and incorporated in the EEC.

These arguments clearly carry weight with the present government. Structural adjustment to imports can be expensive, aid (even in the form of British exports) has some balance of payments and budgetary costs. As the intention is to cut the public sector draconically, it would be surprising to see its external component enhanced. Many businessmen, academics and trade union constituencies recognise this conclusion, even if they do not accept the general policy.

\section{'Doing Well by Doing Good'?}

The Brandt Report views the ethical case for assisting in overcoming absolute poverty quite explicitly as consistent with mutual interest, both sectorally (eg, energy, food, freer trade) and at macro level (demand and trade reflation to raise capacity utilisation and real output). It does not claim that the arguments are identical, but it does view them as reinforcing.

This approach has been criticised. It can be seen as muddling two basically separate - even competitivecases and leading to mistakes on both the "poverty eradication' and mutual interest building fronts. ${ }^{18}$ It is not self-evident that the interests of, say, Brazil, Hong Kong or Saudi Arabia have much in common with the anti-poverty goals of, say, Bangladesh or Tanzania. Strong overlaps may exist in certain cases-eg, India, Indonesia - but even here what benefits local dominant economic interests in Britain and in India and Indonesia may or may not benefit the poor people of the two developing countries.

Further, it is not clear that aid or mutual interest agreements with some states are ethically sound. The objections vary according to the world view of their proponents, but association with many states, eg, Angola, Afghanistan, Vietnam, Mozambique, Nicaragua, El Salvador, Chile, Malawi, Kenya, Indonesia and South Africa has been challenged on ethical grounds. Finally, even if Brandt is correct, 'doing well by doing good' as an approach may arouse such profound suspicion as to be counterproductive. ${ }^{14}$ This particular strand of dissent from Programme for Survival is critical because it splits and neutralises many of the intellectuals, middle class professionals and voluntary organisations who- in Britain - have been the most vocal proponents of aid and of international economic reform or restructuring. 
'Farewell, a long Farewell to all my Greatness . . .' There is finally a quite different type of opposition to Brandt, rarely stated but rooted deep in the economic, intellectual and bureaucratic establishment. This is a profound pessimism as to Britain's ability to respond creatively - or even to cope satisfactorily - with rapid change. Clearly, to the extent that this perception - true or false-governs action, the UK will seek to postpone, slow down and limit change without actually causing head-on confrontation. This was precisely broad UK strategy on international economic relations over 1974-80 (excluding EEC entry, which was more or less irreversibly decided before then).

This opposition to Brandt is not only influential but logical if its premise that the UK has entered inevitable decline and declines more rapidly under conditions of rapid change is correct. This view is not, of course, held by the present government, nor was it by $\mathrm{Mr}$ Heath when he was Prime Minister, but it remains the dominant establishment and perhaps the dominant enterprise and union weltanschaung. As such it is influential and-by inertia if nothing else - as opposed to the 'mutual interest in structural change' argument of Programme for Survival as it was to the much more radical 'recognition of changed realities and international equity' argument for the original Third World NIEO proposals of 1974-75.

Clearly no group can hold all these objections to Programme for Survival at once. Many opponents support only a few. The widest appeal probably lies in the uncertainty and inherent danger of arguments for change - each of the others taken separately probably has minority support individually, politically or in terms of economic groupings.

However, because the different objections have different constituencies the sum total is a majority of decision takers-and probably of the general public - who are at best agnostic and mildly opposed, and in a few cases deeply opposed to Programme for Survival. It is doubtful that this is a strong consensus, or that a strong proBrandt coalition (even if a minority) could not reverse it. But there is no strong pro-Brandt coalition: its natural supporters tend to criticise it as too unrigorous, too much of a compromise, mixing ethics and economics. In the absence of a cogent statement of detailed examples, the potential economic audience for the 'overlapping interest' argument remains unconvinced. Under such conditions a host of divergent objections to the Report, cogently argued, can destroy its impact.

\section{Counters to Objections to the Report}

It is not the primary purpose of this essay to make the case for Programme for Survival. ${ }^{21}$ nor to suggest what coalition in support of it might have a substantial impact on British policy. However, if our reasoned summary of the objections is not to become a de facto case for the prosecution, a note of the counter queries to which those objections are open is required.

Uncertainty is a factor surrounding all major decisions. If it were to be accepted as a reason for rejection, few policy changes would ever be adopted: certainly not the 1978-80 policies of the present government, EEC entry, the decision to fight over Poland in 1939, the proposed platform of Labour's National Executive Committee, the new service forms of the Church of England!21 The real question is whether the probable gains outweigh the probable costs and are large enough to justify taking a risk. Moreover, not acting-ie letting things drift - is equally uncertain, especially in a context like the new international economic disorder.

In respect of the monetarist objection several issues are open. It is clearly open to debate whether the record of British economic policy over 1979-81 is a success. It is even more open to debate whether it is actually monetarism. ${ }^{22}$ However, two additional points can be made in the context of the Brandt Report.

First, its main thrust is not toward raising total international liquidity but on rechannelling (transferring) it to increase output. That is not necessarily inflationary, indeed it can reduce inflationary pressure even within a monetarist frame of reference.

Second, the reasons usually adduced why domestic Keynesianism is unworkable are that (especially in the UK) demand goes into imports, creating a payments crisis, and that institutional rigidities cause inflation long before full capacity or full employment output. The first critique cannot hold globally (there is no Earth payments deficit with Mars!) and the second very well may not. Global Keynesianism may be practicable when the domestic British version is not and it may even be the precondition for British domestic Keynesianism to be practicable.

Whether the 1945-70 period was 'golden' for the Third World is open to doubt. Per capita income rose very slowly and absolute output divergences increased, as did the total number of persons illiterate, hungry, sick and in absolute poverty. In any event, reconstructing the old order is not a serious proposition. ${ }^{23}$ The post1973 world - whose trends are hardly favourable, especially post-1978, to the Third World or to the UK - is its progeny. Some coherent action to halt the rise of disorder and achieve a new, broadly agreed set of 'rules of the game' and institutions is clearly needed. 
Anti-interventionism is in many ways a debating point. Giving limited liability to companies is intervention. (Adam Smith opposed it as inconsistent with the conditions necessary for his 'invisible hand' to operate.) Giving government a monopoly on currency issue and control over credit is intervention. (Professor von Hayek opposes both most vehemently.) Providing another $£ 1,000 \mathrm{mn}$ to British Leyland is intervention (and most uncertain as to results).

No actual capitalist or mixed economy can operate without substantial state intervention in market management. The question is not a macro 'whether' but micro 'when', 'where', 'how' and 'how much'. It is logical to suppose that this is true internationally, and that the present growing disorder at that level is evidence of need for, at the least, altered forms, policies and institutions of intervention.

The public finance implications of Programme for Survival are not massive. The basic reflation/recycling component is envisaged as on commercial account and to the extent that it increased UK exports, production and profits and decreased unemployment it would, in fact, reduce the Public Sector Borrowing Requirement. The concessional finance proposals of $£ 8,000 \mathrm{mn}$ globally might imply $£ 300-400 \mathrm{mn}$ gross for UK, less 'clawback' through reduced unemployment costs and additional tax revenue on production, wages, profits. ${ }^{24}$ This is not a negligible sum, neither is it a huge one in the context of the UK budget.

If the 'muddling through' argument is taken to mean a need to keep different cases for international change separate, and recognise that in practice there are wide variations in their force, complementarity and exact nature, it is correct. But it is not evident that the mutual interest and ethical arguments are normally contradictory. For example, increasing Third World food shortages have negative implications for UK exports and for UK domestic food prices. They also raise ethical imperatives linked to malnutrition and starvation. Are the two lines of argument inherently contradictory? Is it impossible (or immoral) to use both to construct a case stronger than either of its two parts? $?^{25}$

The 'inevitable decline' opposition to Brandt is of course part of a much broader outlook. Is that outlook necessarily correct? (Of course, so long as it is acted on it is probably self fulfilling.) Does concentrating on limiting and delaying change rather than seeking to adjust to or capitalise on it actually reduce or increase the costs of (benefits from) change? Why has the UK had greater transitional and adjustment problems than other 'mature industrial economies', eg, Netherlands, Belgium? Is there really anything inevitable about the causes?

\section{Where and What Now?}

Querying the logic or intellectual force of the ideas advanced by those individuals and groups opposing Programme for Survival does not in itself offer any answer to the question of what to do instead, in modification of or in addition to the Brandt Report proposals. There is fairly broad agreement on some of the basic points made in the Programme for Survival: they constitute common ground between the IMF (in World Economic Outlook), Heath, Bird and-to a lesser extent - Henderson, ${ }^{2 \dagger}$ and can be summarised as follows:

1. the present realities of international economic relations are not satisfactory from the point of view of 'British interests';

2 . in the absence of new initiatives no major improvement can reasonably be expected before the middle of the 1980s (if then);

3. the structural problems of the British economy have not been solved-indeed, high interest rates and a high pound combined with low profits have exacerbated them for manufacturing in particular;

4. the substantial proportion (about 30 per cent) of British exports sold to developing countries implies that a significant fall in their growth rates or import capacity could worsen Britain's export and manufacturing sector problems;

5. projecting present balance of payments trends for Third World economies (excluding major oil exporters) leads inexorably to the conclusion that they will be forced to cut imports and growth unless a structural increase in exports to industrial economies and/or alterations to facilitate increased (or even sustained) resource transfers (commercial and/or concessional) can be achieved.

These do seem to imply a British interest in promoting action at the structural level in the international economic system and in particular, its North-South aspect, ${ }^{27}$ and a need for concerted action through a number of instruments in a number of sectors. If that conclusion is correct, inaction or marginal responses to disorders and crises are likely to prove a very poor second best.

At the present time the only coherent strategic package of proposals which has even potential 'political saleability' at international level is Programme for Survival. Its opponents have not, to date, produced a comparable monetarist (or other) alternative strategy to grapple with the North-South aspects of the new international economic disorder. This is intellectually and, more important, practically, not a satisfactory situation.

It is of course not novel-the whole NIEO debate from the early 1970 s on has been characterised by the 
tabling of a series of south strategy/programme package proposals and a corresponding series of attempts at 'honest brokerage' or 'negotiated compromise' also take into account technical, practical, political and north interest limitations. On the North side-particularly in the UK - the response has been to debate, delay, raise technical queries and objections and agree to marginal action-but neither to accept major structural changes nor to make substantial counter-proposals. This is a satisfactory approach only if present trends are acceptable to the UK and are consistent with international economic stability. Neither of these conditions appears to be the case.

\section{What Might be Done?}

The implications for those who support and those who oppose the Programme for Survival are rather different. For the proponents there is a need to consider the nature of the opposition and its arguments as a first step in deciding whether to try and convince significant economic and political groups that Programme for Survival should be acted upon, or to push for a tactically modified package, ${ }^{28}$ or to redraft, ${ }^{24}$ and how these things should be done.

The opponents have a somewhat different obligation, namely, to produce an alternative strategy or programme for the resolution of the intensifying international economic disorder and to make out a coherent case for their ability to succeed. One such case might be monetarist - none has yet been produced in enough detail to qualify as a proposal for the structural reform of the international economic system. ${ }^{30}$ Another might be centred on a massive expansion of TNC activity in the south. A third could be a demonstration that, contrary to the 1970-81 record and almost all present projections, the Old International Economic Order remains basically viable and dynamic, so that 'steady as you go' policies are adequate and appropriate.

Programme for Survival's own survival as a focus for debate is very much in doubt, and if its opponents do not offer any alternatives this could be the worst outcome. Proponents of the Brandt Report should examine the nature of the opposition to it more carefully, and seek to counter it or to modify the aspects of the programme which are objected to. The opponents, for their part, should put forward their own preferred courses of action to allow for real debate and choice among alternative positive options.

\section{Notes}

1. In 'The Controversial Economics of the Brandt Report', reproduced in this Bulletin.
2. 'Survival, Development and the Report of the Brandt Commission', World Economy, vol 3 no 1, June 1980, p 115. (Not in portion of Henderson reproduced in this Bulletin.)

3. British Interests and Third World Development, Overseas Development Institue, London, 1980, pp 84-85.

4. In 'One Year After Brandt', reproduced in this Bulletin.

5. For a presentation of NIED see R. H. Green, 'A chance to make sense out of economic chaos'. Times Higher Education Supplement, 23 May 1980.

6. For an example of Third World (and especially oil exporter) criticism of M. S. Wionczek, 'The Brandt Report', Third World Quarterly. vol 3 no 1, January 1980, and for an example of a positive Third World position see A. H. Jamal 'Man at the Centre of Economic Purpose' in the same volume.

7. See Cable, op cit; A. R. Riddell (ed), Adiustment or Protectionism: the challenge to Britain of Third World Industrialisation. Catholic Institute for International Relations, London, 1980 for a fuller discussion of the complex and conflicting interests and perceptions within labour and enterprise.

8. op cit, see 1. above.

9. ibid.

10. See his article, reproduced in this Bulletin.

11. ibid.

12. While arguably church leaders (eg, the Archbishop of Canterbury, Cardinal Archbishop of Westminster, Synod of the Church of England) have a greater degree of commitment, it is much more to the moral than the mutual interest aspects of Programme for Survival and tends to concentrate on aid more than on structural change.

13. This is not intended as disparaging. On secondary issues relating to contexts which are at worst mildly unsatisfactory and not deteriorating rapidly the author, when functioning as technocrat, often shares this view.

14. For a clear summary analysis see Bird's article, reproduced in this Bulletin.

15. See World Economic Outlook. IMF, Washington, 1980 , esp pp 3-10, 39-42.

16. See Henderson, op cit.

17. See Henderson in this Bulletin.

18. eg, Dudley Seers, Third World Quarterly. vol 2 no 4, 1980.

19. cf Cable, op cit, pp 24-25.

20. For the author's views see 'A chance to make sense out of economic chaos', op cit and 'Gale warnings: fragments of charts and guides for navigators', Development Dialogue, no 1,1980 .

21. Presumably no reader will endorse all of these. It is true that under conditions of uncertainty some decisions will be perceived as having been wrong by any individual, interest or sub-class.

22. cf T. Higgins, 'Whatever happened to Monetarism?', Guardian, 26 January 1981, p 7. 
23. The IMF analysis. loc cit. demonstrates this at least as forcefully as Programme for Survival. even if from a quite different economic world view.

24. The British Leyland grant of $£ 1.000 \mathrm{mn}$ over two years has been justified on the basis that tax losses and unemployment costs to government would be larger. More directly to the point. Cable. op cit. pp 74 ff. shows substantial output. employment. public finance 'spin offs' from aid.

25. cf R. H. Green. 'Brandt on an end to poverty and hunger'. Third World Quarterly, vol 3 no 1. January 1981.

26. See the articles by Heath, Bird and Henderson in this volume. Of course the various authors differ to some extent in eg their view of the gravity of the present situation and of current trends.

27. This is not to imply that general North-North or NorthwestNortheast (socialist Europe) issues are less important. However. they fall outside the scope of this essay and are peripheral to the Brandt Report debate.
28. Some opponents, eg Henderson (see this Bulletin) suggest that a substantial proportion of the basic initial programme might have broader support and less opposition if separated from the analysis and medium term programme. This approach has risks, but arguably would produce a forward momentum and allow subsequent changes to be agreed in a less unsatisfactory and uncertain context.

29. Either because they are convinced the Brandt Report is. after all. unsound or because they are convinced there is no chance of achieving substantial implementation of its proposals.

30. Ironically the most coherent monetarist model-albeit one significantly divergent from those of the IMF - addressed to these issues has been presented by a member of the Brandt Commission secretariat: J. F. Rweyemamu's 'Restructuring the international monetary system', Development Dialogue, no 2. 1980. However. that model is advanced as complementary to (or in elaboration of) Programme for Survival. 